\begin{tabular}{|c|c|c|c|c|c|}
\hline SRA (India) & $=3.117$ & SIS (USA) & $=0.912$ & ICV (Poland) & $=6.630$ \\
\hline ISI (Dubai, UAE & $=\mathbf{0 . 8 2 9}$ & РИНЦ (Russia) & $=0.156$ & PIF (India) & $=1.940$ \\
\hline IF (Australia) & $=0.564$ & ESJI (KZ) & $=\mathbf{5 . 0 1 5}$ & IBI (India) & $=4.260$ \\
\hline IF & $=1.500$ & SJIF (Morocco) & $=5.667$ & ОАJI (USA) & $=0.350$ \\
\hline
\end{tabular}

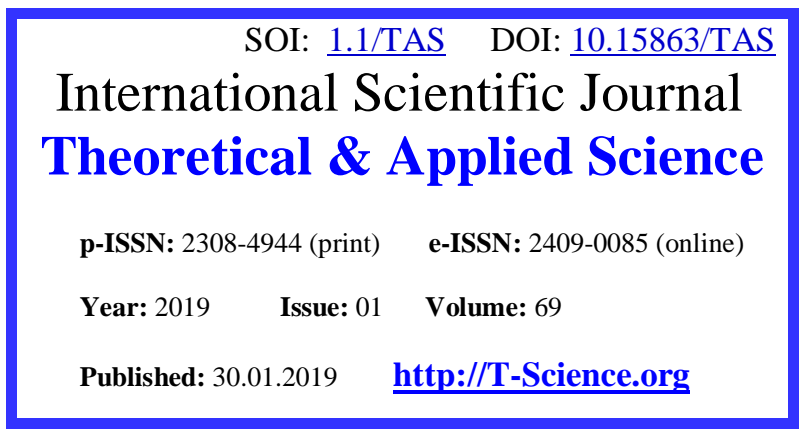

SECTION 9. Chemistry and chemical technology
QR - Issue

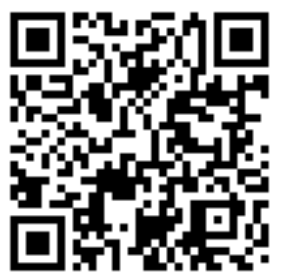

Oleg Ivanovych Yurchenko Kharkiv V.N. Karazin National University, PhD, Full Professor of Chemical Metrology Department, yurchenko@karazin.ua

Tetyana Vasylivna Chernozhuk Kharkiv V.N.

Karazin National University, PhD, Associate Professor of Inorganic Chemistry Department, tanya.chernozhuk@gmail.com

Oleksii Andriovych Kravchenko Kharkiv V.N.

Karazin National University, $\mathrm{PhD}$, Associate Professor of Chemical Metrology Department, alekseykravch@ukr.net

Michail Oleksandrovych Dobrijan Kharkiv V.N. Karazin

National University, Sinjar Researcher of

Chemical Metrology Department, yurchenko@karazin.ua

\title{
ATOMIC-ABSORPTION AND ATOMIC-EMISSION WITH INDUCTIVE CONNECTED PLASMA DETERMINATION OF IRON AND MANGANESE IN THE OIL SAMPLES
}

\footnotetext{
Abstract: In the work a promising method of sample preparation was used - emulsification of the oil sample with subsequent ultrasound treatment. The optimal conditions for the analysis were selected. It was found that the best extraction of Manganese and Iron was observed in emulsions of Triton X-100 aqueous solution with 5\% mass concentration and 20 min. of ultrasound treatment. It was proved that using of the Triton X-100 modifier and the ultrasound treatment of emulsions increases the sensitivity of the detection of Manganese and Iron by 1.5 times. For calibration of measurements for the first time new standard composition samples based on acetylacetonates of Manganese and Iron were used. The variation of the sample weight was shown that the technique does not contain a significant systematic error. The validity of the results has been checked using the "injected-found out" method. The results of two independent methods were compared according to $F$ - and t-criteria. The obtained results were equivalent, the difference between them was not significant and was justified by a random distribution. The detection limits of Iron and Manganese were estimated, which were 0.002 and $0.001 \mathrm{mg} /$, respectively.

Key words: atomic absorption and atomic emission with inductive connected plasma spectroscopy, oil, sample preparation, ultrasound, Triton X-100, Iron, Manganese, metrological characteristics.

Language: English

Citation: Yurchenko, O. I., Chernozhuk, T. V., Kravchenko, O. A., \& Dobrijan, M. O. (2019). Atomicabsorption and atomic-emission with inductive connected plasma determination of iron and manganese in the oil samples. ISJ Theoretical \& Applied Science, 01 (69), 254-260.

Soi: http://s-o-i.org/1.1/TAS-01-69-35 Doi: crossef https://dx.doi.org/10.15863/TAS.2019.01.69.35
} 


\begin{tabular}{|c|c|c|c|c|c|c|}
\hline \multirow{4}{*}{ Impact Factor: } & ISRA (India) & $=3.117$ & SIS (USA) & $=0.912$ & ICV (Poland) & $=6.630$ \\
\hline & ISI (Dubai, UAE & $=0.829$ & РИНЦ (Russia) & $=0.156$ & PIF (India) & $=1.940$ \\
\hline & GIF (Australia) & $=0.564$ & ESJI (KZ) & $=5.015$ & IBI (India) & $=4.260$ \\
\hline & JIF & $=1.500$ & SJIF (Morocco) & $=5.667$ & OAJI (USA) & $=0.350$ \\
\hline
\end{tabular}

\section{Introduction}

The microelement composition of oil is an important characteristic of this type of raw material.

First, it carries geological and geochemical information, indicating, in particular, the age of oil, the way and the direction of its migration and accumulation. Differences in the content of trace elements in petroleum can be used to identify oil reservoirs and recommendations for the use of wells. Secondly, in the near future, because of the tendency of depletion of ore deposits, oil can become a raw material for the production of Vanadium, Nicol, Copper and noble metals [1,p.1324]. Thirdly, trace elements contained in petroleum can have a significant impact on the technological processes of oil refining, causing poisoning of catalysts, corrosion of equipment and getting into significant quantities in the oil products received. The use of such petroleum products as a fuel leads to the release of metals compounds with a toxic effect into the atmosphere. Using them as lubricants causes corrosion of engine active elements [2, p.4].

The combination of the above circumstances shows the necessity and purposefulness of studying the microelement composition of oil as the great interest of many branches of the national economy.

In world practice, some atomic spectral analysis methods are used for the determination of metals in oil: flame atomic absorption spectroscopy (FAAS), electrothermal atomic absorption spectroscopy (ETAAS), optical emission spectroscopy with inductively coupled plasma (AES-ICP), mass spectroscopy with an inductively coupled plasma (MS-ICP)

[3,p.122;4,p.46;5,p.175;6,p.240;7,p.1992;8,p.552;9,p .7;10,p.2;11,p.14;12,p.33;13,p.86;14,p.24;15,p.350;

16, p.235;17,p.262;18,p.137;

19,p.7;20,p.843;21,p.65;22,p.262;23,p.5;24,p.89;25,p $.1412,26$, p.137;27,p.364;28,p.1216;29,p.5909;30,p.6 79;31,p.3009;32,p.632,33,p.137].

The purpose of this work is to select the conditions for sample preparation of the oil sample by emulsification method, as well as to compare the results of Iron and Manganese determination in the sample by methods of atomic absorption and atomic emission with inductive connected plasma spectroscopy, using new standard composition samples.

\section{Experimental part}

In the work were used: 1. Acetylacetone $\mathrm{CH}_{3}$ $\mathrm{CO}-\mathrm{CH}_{2}-\mathrm{CO}-\mathrm{CH}_{3}$ GOST 10259-78, ch.p.; 2. Iron (III) acetylacetonate; 3. Manganese (II) acetylacetonate; 4 . A standard composition sample of the Iron (III) solution according to the SZZ 022.38$96,1 \mathrm{mg} / \mathrm{cm}^{3} ; 5$. Standard composition sample of the Manganese (II) solution according to the SZZ 022.47-96, $1 \mathrm{mg} / \mathrm{cm}^{3}$; 6. Oil; 7. Non-ionic surfactant
Triton X-100 (oxyethylene derivative of alkylphenol) $\mathrm{C}_{14} \mathrm{H}_{22} \mathrm{O}\left(\mathrm{C}_{2} \mathrm{H}_{4} \mathrm{O}\right)_{\mathrm{n}}$ with $n=9-10$<smiles>CC(C)(C)CC(C)(C)c1ccccc1</smiles>

$$
\begin{aligned}
& \mathrm{M}_{\mathrm{r}} \sim 646 \\
& \mathrm{CCM}_{0,06 \mathrm{~g} / \mathrm{l}}=2,9 \cdot 10^{-4}-1,0 \cdot 10^{-1} \mathrm{~mol} / \mathrm{l} . \\
& \text { Yulievsky } \quad \text { SRC } \quad \text { of }
\end{aligned}
$$

SUE "Shebelyngasvydobuvannya". Skvortsevo NGRC, St. 25 ; prod.gor. $\mathrm{B}-16$, the interval of perforation is 3071-3074. Place of selection: collector at the well.

Atomic absorption spectrometer C-115-M1. Measurements were made in the flame of propanebutane-air at optimal determination parameters: $\lambda_{\mathrm{Fe}}=$ $248.3 \mathrm{~nm}, \lambda_{\mathrm{Mn}}=279.3 \mathrm{~nm}$, FEP $=1 \mathrm{kV}$, current $I=5$ $\mathrm{mA}$, width of monochromatic gap - $0.1 \mathrm{~nm}$; lamp with hollow iron cathode; lamp with hollow manganese cathode; atomic emission spectrometer with an inductive connected plasma iCAP 6300 Duo produced by Thermo Scientific, USA. The measurements were carried out according to the instruction "Thermo SPEC/PMT software for TJA Sequential ISAP Spectrometers Getting started. Part Number 140962-00". Optimal measurement conditions: $\lambda_{\mathrm{Fe}}=259.940 \mathrm{~nm}, \lambda_{\mathrm{Mn}}=283.534 \mathrm{~nm}$, peristaltic pump rotation speed - $100 \mathrm{rpm}$, argon flow pressure during spraying - $30 \mathrm{psi}$, integration time - 2 sec, plasma power - $1500 \mathrm{~W}$; ultrasonic dispersant PS-20. Optimal operating parameters: working power $120 \mathrm{~W}$, frequency $40 \mathrm{kHz}$; laboratory electronic balance meets all requirements of TU U 292-32126739-032005.

For the preparation of Triton X-100 aqueous solutions, calculated weight of this substance was dissolved in water in the $200 \mathrm{ml}$ volumetric flask.

The aqueous solutions of Triton X-100 were obtained: $4,7 \cdot 10^{-2}(3 \%) ; 6,3 \cdot 10^{-2}(4 \%) ; 7,9 \cdot 10^{-2}(5 \%)$; $9,5 \cdot 10^{-2}(6 \%) \mathrm{mol} / \mathrm{l}$.

Preparation of standard aqueous solutions of Iron and Manganese

The initial solutions of Iron and Manganese with concentration $0.1 \mathrm{~g} / \mathrm{l}$ were prepared by diluting standard solution samples of these metals (with concentration of metals $1 \mathrm{mg} / \mathrm{ml}$ ) with distilled water.

For the preparation of intermediate solutions of Iron and Manganese with concentration $5 \cdot 10^{-3} \mathrm{~g} / \mathrm{l}$, previously prepared initial solutions were used.

Preparation of calibration solutions series based on metals acetylacetonates

Metals acetylacetonates were used for approximation the composition of the analyzed sample and the calibration solutions, that increases reproducibility and accuracy of the determination. 


\begin{tabular}{|c|c|c|c|c|c|c|}
\hline \multirow{4}{*}{ Impact Factor: } & ISRA (India) & $=3.117$ & SIS (USA) & $=0.912$ & ICV (Poland) & $=6.630$ \\
\hline & ISI (Dubai, UAE & $=0.829$ & РИНЦ (Russia & $=0.156$ & PIF (India) & $=1.940$ \\
\hline & GIF (Australia) & $=0.564$ & ESJI (KZ) & $=\mathbf{5 . 0 1 5}$ & IBI (India) & $=4.260$ \\
\hline & JIF & $=1.500$ & SJIF (Morocco & $=5.667$ & OAJI (USA) & $=0.350$ \\
\hline
\end{tabular}

From the initial saturated solutions of metals acetylacetonates with known concentrations of Iron and Manganese, $131.3 \mathrm{mg} / \mathrm{L}$ and $195.73 \mathrm{mg} / \mathrm{L}$, respectively, the solution with a concentration of $5 \cdot 10^{-3} \mathrm{~g} / \mathrm{dm}^{3}$ was prepared by successive dilution. Then, this solution was used to prepare a series of 5 calibration solutions with concentrations of Iron and Manganese $1 \cdot 10^{-4} ; 3 \cdot 10^{-4} ; 5 \cdot 10^{-4} ; 7 \cdot 10^{-4} ; 10 \cdot 10^{-4}$ $\mathrm{g} / \mathrm{dm}^{3}$. For this, the aliquot of the solution was transferred to the $10 \mathrm{~cm}^{3}$ volumetric flask, $4 \mathrm{~cm}^{3}$ of Triton X-100 solution $(\omega=5 \%)$ and $1 \mathrm{~cm}^{3}$ of concentrated nitric acid were added and diluted to scale by distilled water. In the case of preparation of calibration solutions for Manganese, $0.2 \mathrm{~cm}^{3}$ of acetylacetone was added. The prepared solutions were placed in the ultrasonic dispenser PS-20 for 20 $\min$.

Preparation of a series of calibration metal solutions based on standard aqueous solutions. In 10 $\mathrm{cm}^{3}$ volumetric flask $0.2,0.6,1.0,1.4,2.0 \mathrm{~cm}^{3}$ of metals solution with concentration of $5 \cdot 10^{-3} \mathrm{~g} / \mathrm{dm}^{3}$ were transferred, diluted to scale by distilled water and stirred. We got a series of 5 calibration solutions with metals concentrations $1 \cdot 10^{-4} ; 3 \cdot 10^{-4} ; 5 \cdot 10^{-4} ; 7 \cdot 10^{-}$ 4; $10 \cdot 10^{-4} \mathrm{~g} / \mathrm{dm}^{3}$.

The emulsification was chosen as a method for oil sample preparation before analysis.

To $1 \mathrm{~g}$ of oil $1.0 \mathrm{~cm}^{3}$ of concentrated nitric acid and $4 \mathrm{~cm}^{3}$ of Triton X-100 aqueous solution $(\omega=$ $5 \%$ ) were added. For Manganese determination, 0.2 $\mathrm{cm}^{3}$ of acetylacetone was added. Solution was stirred with a magnetic stirrer for 40 minutes. The prepared emulsion was then treated with ultrasound disperser PS-20 for $20 \mathrm{~min}$. The sample solution was quantitatively transferred into $10 \mathrm{~cm}^{3}$ volumetric flask, diluted to scale by distilled water. Thus, stable and homogeneous emulsions were obtained.

\section{Results and discussion}

An important property of micellar solutions of surfactant in water is their ability to solubilize (colloidal solution) of substances that are almost insoluble in water. In this work, the Triton X-100 surfactant was used. Based on the results of previous studies of using Triton X-100, Bridg-35 and Twin-20 for the sample preparation of oil products it was shown that the most complete element extraction was observed with the application of Triton X-100. Using this surfactant, homogeneous emulsions have been obtained, which have considerable stability in time. For comparison: when using Bridge-35, a few drops of oil appeared on the solution surface, while the Twin-20 emulsions were unstable and there was a system bundle immediately after mixing, without the recovery possibility.

The dependence of the results of atomicabsorption metals determination on the concentration of Triton X-100 has been investigated. It was shown that the maximum value of the concentration of Iron and Manganese was in the sample with Triton X-100 mass fraction of $5 \%$ (Table 1 ).

The time of the prepared emulsions ultrasound treatment was determined. For this, the emulsions were treated with ultrasound for a different periods of time. US is usually used to create stable emulsions of oil products that do not decompose within 5 days. The obtained emulsions are transparent and homogeneous. The dependence of the Iron and Manganese concentration in oil from the time of ultrasound treatment is presented in Table 2. From the obtained results it is clear that the maximum of the analytical signal is reached for 20 minutes of ultrasound treatment.

The quantitative characteristic of sensitivity during the atomic absorption determination is the sensitivity coefficient, which is the derivative of the analytical signal on the concentration of the element.

$$
S=\operatorname{tg} \alpha=\frac{d A}{d c}
$$

If the dependence is linear, the sensitivity coefficient can be determined by the inclination of the linear part of the calibration graph.

From these dependencies, we can conclude that the sensitivity of Iron and Manganese increases by 1.5 times.

The atomic absorption determination of the Iron and Manganese is given in the Table 3.

In order to verify the correctness of the metals determination in oil, the method "injected-found out" was used. The analysis was carried out by a fiery atomic absorption method. The results of the measurements are given in the Table 4 .

An estimation of the systematic error of the Iron and Manganese determination was made by variation of the oil sample weight (Table 5). It was shown that there was no significant systematic error.

The results of the atomic emission with inductive connected plasma determination of Iron and Manganese in the oil samples are given in the Table6.

The results of the Iron and Manganese determination by atomic absorption and atomic emission with inductive connected plasma methods were compared according to $F$ - and $t$-criteria (Table 7).

Since $F<F_{\text {table }}$ and $t<t_{\text {table }}(F=6.39 ; t=2.31)$, we can conclude that the obtained results are equivalent, the difference in the reproducibility is random, and the difference in mean obtained by two independent methods is negligible and justified by accidental dispersal.

The limits of detection of the atomic absorption determination of Iron and Manganese were estimated. The calculation of the detection limit was 


\begin{tabular}{|c|c|c|c|c|c|c|}
\hline \multirow{4}{*}{ Impact Factor: } & ISRA (India) & $=3.117$ & SIS (USA) & $=0.912$ & ICV (Poland) & $=6.630$ \\
\hline & ISI (Dubai, UAE & $=0.829$ & РИНЦ (Russia & $=0.156$ & PIF (India) & $=1.940$ \\
\hline & GIF (Australia) & $=0.564$ & ESJI (KZ) & $=5.015$ & IBI (India) & $=4.260$ \\
\hline & JIF & $=1.500$ & SJIF (Morocce & $=5.667$ & OAJI (USA) & $=0.350$ \\
\hline
\end{tabular}

carried out according to the formula $C_{\min }=\frac{3 \cdot S_{0}}{k}$, where $S_{0}$ is the standard deviation of the background signal, which can be found by the formula $S_{\mathbf{0}}=\sqrt{\frac{\sum_{i=\mathbf{1}}^{n}\left(\bar{A}-A_{i}\right)}{n-\mathbf{1}}}$, where $k$ is the angular coefficient of the calibration function.

Calibration solutions were prepared to determine the detection limit of these elements, as follows: $x \mathrm{ml}$ of metal acetylacetonate with a concentration of $5 \cdot 10^{-3} \mathrm{~g} / 1$ were mixed with $4 \mathrm{ml}$ of Triton X-100aqueous solution $(\omega=5 \%)$, then diluted to scale by distilled water, stirred and treated by ultrasound for 20 minutes. During the Manganese determination $0.2 \mathrm{ml}$ of acetylacetone were added.

We also prepared 20 bulk solutions, that means, add in everything except metals acetylacetonates.
The analytical signal $(A)$ for 20 bulk solutions was determined and $\mathrm{C}_{\min }$ was calculated.

The detection limits of Iron and Manganese by this technique are 0.002 and $0.001 \mathrm{mg} / \mathrm{l}$ respectively, which is less than literature data.

\section{Conclusions}

The use of Triton X-100 aqueous solutions and ultrasound treatment eliminates the use of toxic and expensive reagents, increases stability and homogeneity of the obtained emulsions, reduces the samples preparation time for analysis, increases the sensitivity of the determination. New standard composition samples based on the metals acetylacetonates approximate the composition of calibration solutions to the analyzed solutions, which greatly increases the precision and accuracy of measurements.

Table 1. Selection of Triton X-100 concentration for atomic-absorption determination of Iron and Manganese $(\mathrm{n}=5, \mathrm{P}=\mathbf{0 . 9 5})$.

\begin{tabular}{|c|c|c|c|c|}
\hline \multirow{2}{*}{$\omega, \%$} & \multicolumn{2}{|c|}{$\mathrm{Mn}, \mathrm{mg} / \mathrm{kg}$} & \multicolumn{2}{c|}{$\mathrm{Fe}, \mathrm{mg} / \mathrm{kg}$} \\
\cline { 2 - 5 } & $\bar{C} \pm \frac{t_{P, f} \cdot S}{\sqrt{n}}$ & & $\bar{C} \pm \frac{t_{P, f} \cdot S}{\sqrt{n}}$ & $S_{r}$ \\
\hline 3 & $3,67 \pm 0,04$ & 0,01 & $0,70 \pm 0,01$ & 0,01 \\
\hline 4 & $3,74 \pm 0,05$ & 0,01 & $0,72 \pm 0,01$ & 0,01 \\
\hline 5 & $3,82 \pm 0,05$ & 0,01 & $0,74 \pm 0,02$ & 0,02 \\
\hline 6 & $3,82 \pm 0,05$ & 0,01 & $0,73 \pm 0,02$ & 0,02 \\
\hline
\end{tabular}

Table 2. Selection of the ultrasound treatment time of the analyzed solutions under the atomic absorption determination of Iron and Manganese $(n=5, P=0.95)$.

\begin{tabular}{|c|c|c|c|c|}
\hline $\begin{array}{c}\text { Time of the } \\
\text { treatment, min. }\end{array}$ & \multicolumn{2}{|c|}{$\mathrm{Mn}, \mathrm{mg} / \mathrm{kg}$} & \multicolumn{2}{c|}{$\mathrm{Fe}, \mathrm{mg} / \mathrm{kg}$} \\
\cline { 2 - 5 } & $\bar{C} \pm \frac{t_{P, f} \cdot S}{\sqrt{n}}$ & $\mathrm{~S}_{\mathrm{r}}$ & $\bar{C} \pm \frac{t_{P, f} \cdot S}{\sqrt{n}}$ & $\mathrm{~S}_{\mathrm{r}}$ \\
\hline 10 & $0,68 \pm 0,02$ & 0,01 & $3,72 \pm 0,05$ & 0,01 \\
\hline 15 & $0,71 \pm 0,01$ & 0,01 & $3,79 \pm 0,05$ & 0,01 \\
\hline 20 & $0,74 \pm 0,02$ & 0,02 & $3,83 \pm 0,05$ & 0,01 \\
\hline 25 & $0,73 \pm 0,01$ & 0,02 & $3,83 \pm 0,05$ & 0,01 \\
\hline
\end{tabular}

Table 3. Results of the Iron and Manganese determination by the AAS method in oil emulsions using Triton $X-100$ and ultrasound stabilization $(n=5, P=0.95)$

\begin{tabular}{|c|c|c|}
\hline \multirow{2}{*}{ Metal } & \multicolumn{2}{|c|}{ AAS } \\
\cline { 2 - 3 } & $\bar{C} \pm \frac{t_{P, f} \cdot S}{\sqrt{n}}, \mathrm{mg} / \mathrm{kg}$ & $\mathrm{S}_{\mathrm{r}}$ \\
\hline Iron & $3,83 \pm 0,04$ & 0,01 \\
\hline
\end{tabular}




\begin{tabular}{|c|c|c|c|c|c|c|}
\hline \multirow{4}{*}{ Impact Factor: } & ISRA (India) & $=3.117$ & SIS (USA) & $=0.912$ & ICV (Poland) & $=6.630$ \\
\hline & ISI (Dubai, UAE & $=0.829$ & РИНЦ (Russia) & $=0.156$ & PIF (India) & $=1.940$ \\
\hline & GIF (Australia) & $=0.564$ & ESJI (KZ) & $=5.015$ & IBI (India) & $=4.260$ \\
\hline & JIF & $=1.500$ & SJIF (Morocco) & $=5.667$ & OAJI (USA) & $=0.350$ \\
\hline
\end{tabular}

\begin{tabular}{l|l|l} 
Manganese & $0,77 \pm 0,01$ & 0,01
\end{tabular}

Table 4. Verification of the correctness of the Iron and Manganese atomic absorption determination in oil emulsions stabilized by the US method "injected-found out" $(n=5, P=0.95)$

\begin{tabular}{|c|c|c|c|c|}
\hline Metal & Contain, $\mathrm{mg} / \mathrm{kg}$ & Injected, $\mathrm{mg} / \mathrm{kg}$ & $\begin{array}{c}\text { Found out, } \\
\mathrm{mg} / \mathrm{kg}\end{array}$ & $\mathrm{S}_{\mathrm{r}}$ \\
\hline Iron & 3,83 & 4,00 & $7,80 \pm 0,09$ & 0,01 \\
\hline Manganese & 0,77 & 1,00 & $1,73 \pm 0,04$ & 0,02 \\
\hline
\end{tabular}

Table 5. Estimation of the systematic error in the atomic absorption determination of Iron and Manganese by variation of the sample weight $(n=5, P=0.95)$

\begin{tabular}{|c|c|c|c|c|}
\hline \multirow{2}{*}{$\begin{array}{c}\text { Weight of the } \\
\text { samples, }\end{array}$} & $\overline{2}$ & $\mathrm{Mn}, \mathrm{mg} / \mathrm{kg}$ & \multicolumn{2}{c|}{$\mathrm{Fe}, \mathrm{mg} / \mathrm{kg}$} \\
\cline { 2 - 5 } & $\bar{C} \pm \frac{t_{P, f} \cdot S}{\sqrt{n}}$ & & $\bar{C} \pm \frac{t_{P, f} \cdot S}{\sqrt{n}}$ & $\mathrm{~S}_{\mathrm{r}}$ \\
\hline 0,5 & $0,83 \pm 0,02$ & 0,02 & $3,52 \pm 0,04$ & 0,01 \\
\hline 1,0 & $0,85 \pm 0,03$ & 0,01 & $3,51 \pm 0,04$ & 0,01 \\
\hline 1,5 & $0,84 \pm 0,03$ & 0,02 & $3,46 \pm 0,04$ & 0,01 \\
\hline
\end{tabular}

Table 6. Results of the Iron and Manganese determination by NPP-IRPs method in oil emulsions using Triton X-100 and ultrasound stabilization $(n=5, P=0.95)$

\begin{tabular}{|c|c|c|}
\hline \multirow{2}{*}{ Metal } & \multicolumn{2}{|c|}{ AES-ICP } \\
\cline { 2 - 3 } & $\bar{C} \pm \frac{t_{P, f} \cdot S}{\sqrt{n}}, \mathrm{mg} / \mathrm{kg}$ & $\mathrm{S}_{\mathrm{r}}$ \\
\hline Iron & $3,87 \pm 0,05$ & 0,01 \\
\hline Manganese & $0,80 \pm 0,02$ & 0,02 \\
\hline
\end{tabular}

Table 7. Coherence of the results of AAS and NPP-IRPs determination of Iron and Manganese in the oil sample stabilized by ultrasound, according to Fisher and Student criteria

\begin{tabular}{|c|c|c|c|}
\hline Metal & $F$ & $S_{1,2}$ & $t_{1,2}$ \\
\hline Iron & 2,36 & 0,0430 & 1,47 \\
\hline Manganese & 2,44 & 0,0495 & 0,95 \\
\hline
\end{tabular}




\begin{tabular}{|c|c|c|c|c|c|c|}
\hline \multirow{4}{*}{ Impact Factor: } & ISRA (India) & $=3.117$ & SIS (USA) & $=0.912$ & ICV (Poland) & $=6.630$ \\
\hline & ISI (Dubai, UAE & $=0.829$ & РИНЦ (Russia & $=0.156$ & PIF (India) & $=1.940$ \\
\hline & GIF (Australia) & $=0.564$ & ESJI (KZ) & $=\mathbf{5 . 0 1 5}$ & IBI (India) & $=4.260$ \\
\hline & JIF & $=1.500$ & SJIF (Morocco & $=5.667$ & OAJI (USA) & $=0.350$ \\
\hline
\end{tabular}

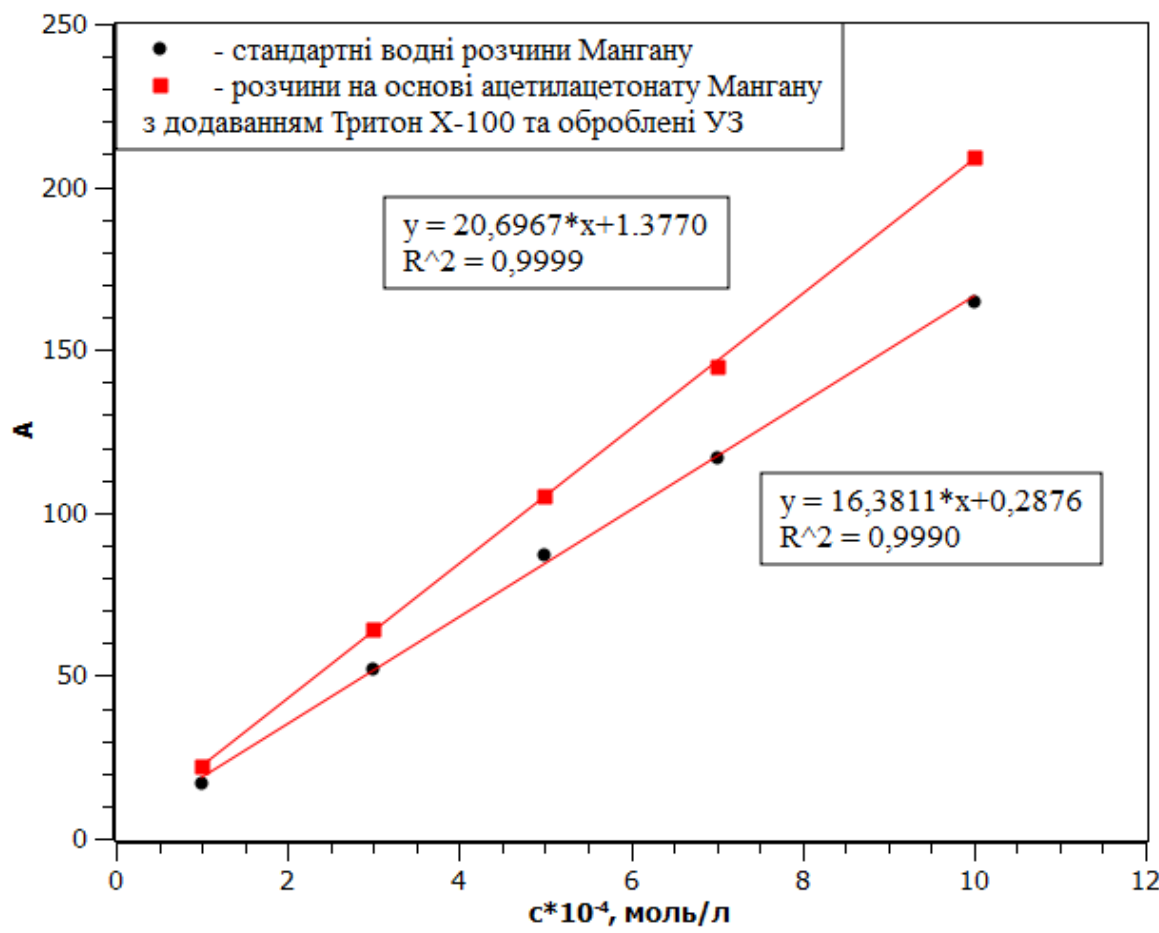

Figure 1. Dependence of the Iron analytical signal in aqueous solutions and in manganese acetylacetonate solutions with addition of Triton X-100 from the Iron concentration for atomic absorption determination

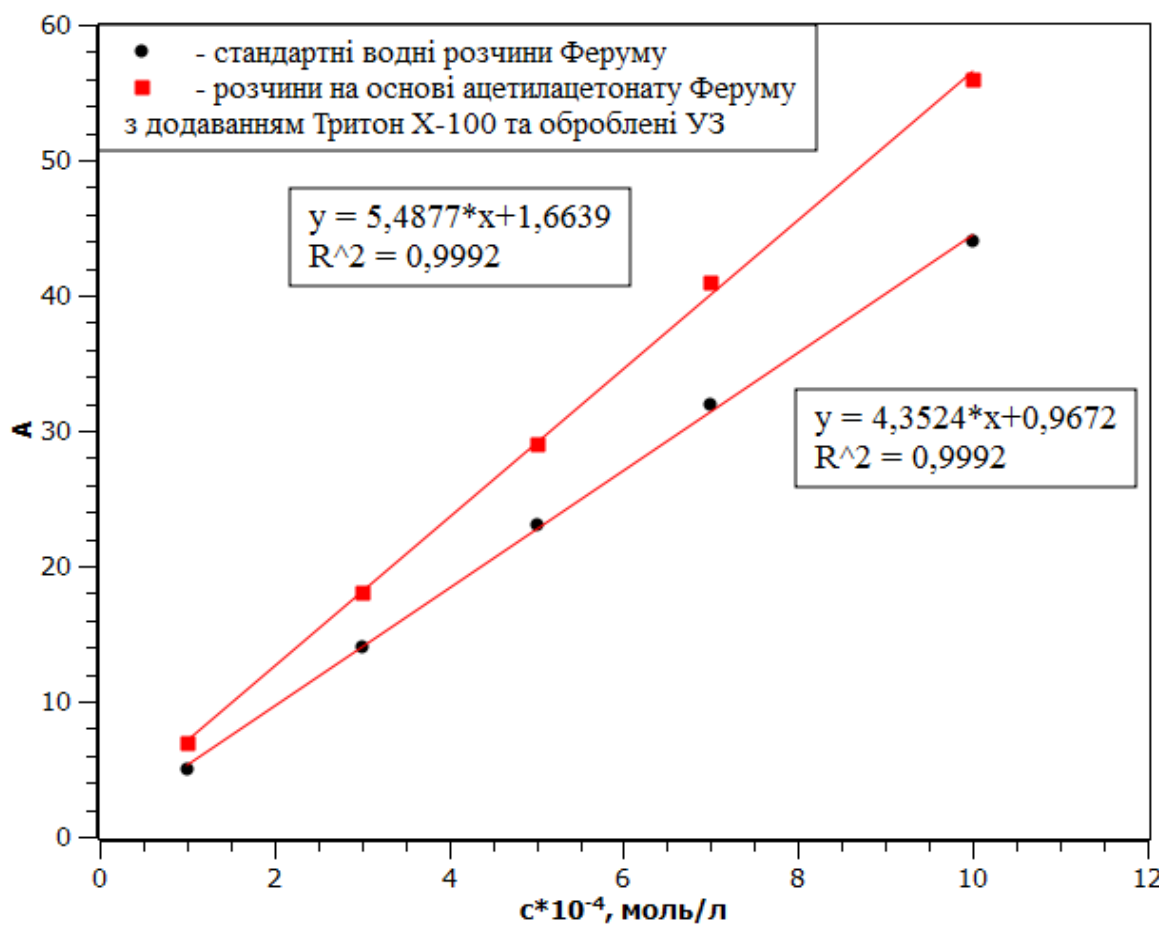

Figure 2. Dependence of the Manganese analytical signal in aqueous solutions and in manganese acetylacetonate solutions with addition of Triton X-100 from the Manganese concentration for atomic absorption determination 


\begin{tabular}{|c|c|c|c|c|c|c|}
\hline \multirow{4}{*}{ Impact Factor: } & ISRA (India) & $=3.117$ & SIS (USA) & $=0.912$ & ICV (Poland) & $=6.630$ \\
\hline & ISI (Dubai, UAE & $=0.829$ & РИНЦ (Russia) & $=0.156$ & PIF (India) & $=1.940$ \\
\hline & GIF (Australia) & $=0.564$ & ESJI (KZ) & $=5.015$ & IBI (India) & $=4.260$ \\
\hline & JIF & $=1.500$ & SJIF (Morocco) & $=5.667$ & OAJI (USA) & $=0.350$ \\
\hline
\end{tabular}

\section{References:}

1. Shabanova, G. (1988). J. anal. chem. V. 43, 1323-1328.

2. Lurie, M. A. (2003). Himiya masel, V.1, 3-5.

3. Nadirov, N. K., \& Kotova, A. V. (1984). Metals in oil. (p.448). Alma-Ata.

4. Mir-Babaev, M. F. (1997). Himiya masel, V 5, 46-47.

5. Aleshin, G. N. (1990). Neftehimia, V. 30, 175-183.

6. Schwarzer, M., Schuster, M., von Hentig, R. (2002). Fresenius' journal of analytical chemistry, V. 368, 240-243.

7. Saint'Pierre, T. D., et al. (2002). Spectrochimica Acta Part B: Atomic Spectroscopy, V. 57, 1991-2001.

8. Saint'Pierre, T. D., et al. (2004). Spectrochimica Acta Part B: Atomic Spectroscopy, V. 59, 551-558.

9. (2004). ISO International Standard, ISO 3170. Petroleum liquids-manual sampling.

10. (2011). Annual Book of ASTM Standards, ASTM D 4057-06, Standard Practice for Manual Sampling of Petroleum and Petroleum Products, 2006 (reapproved 2011).

11. Beisel, N. F. (2008). Atomic absorption spectrometry. (pp.13-16). NGU.

12. Lvov, B. V. (1966). Atomic absorption spectral analysis. (pp.32-37). Moscow: Nauka.

13. Pupishev, A. A. (2002). Atomic emission spectral analysis with inductive connected plasma according to Grimm. (pp.85-87). UPI.

14. Nölte, J. (2003). Wiley-VCH. Hoboken, V. 3, 19-25.

15. Amorim, F. A. C., \& Welz, B. (2007). Talanta V.72, 349-359.

16. Mester, Z., \& Sturgeon, R. E. (2003). Elsevier, V. 41, 235.
17. Hammond, J. L., \& Leea, Y.-M. (2008) Talanta, V. 47, 261-266.

18. Souza, R. M., \& Meliande, A.L.S. (2006) Microchem. J. V. 82, 137-147.

19. (n.d.). ATSM D 5863 - 2000. Standard test method for determination of nickel, vanadium, iron and sodium in crude oils and residual fuels by flame atomic absorption spectrometry.

20. Anjos, S. L. (2018). Talanta, V. 178, 842 - 846.

21. Yang, W., \& Casey, J. F. (2017). Elsevier, V, 206, $64-79$.

22. Hammond, J. L., \& Leea, Y.-M. (2008). Talanta, V. 47, 261-266.

23. Pereira, J. S. F., et al. (2010). Microchemical Journal, V. 96, 4-11.

24. Barela, P. S. (2017). Elsevier, V. 204, 85 - 90.

25. Kunina, D. (1988). J. anal. chem. V. 43, 14111413.

26. Vale, M. G. R., \& Damin, I. C. F. (2004). V, 77, $131-140$.

27. Guidroz, J. M., \& Sneddon, J. (2002). Microchemical journal, V. 73, 363-366.

28. Cassella, R. J., et al. (2011). Fuel, V. 90, 12151220.

29. Quadros, D. P. C., et al. (2010). Energy \& Fuels, V. 24, 5907-5911.

30. Stukov, S. N. (2000). J. anal. chem. V. 55, 679686.

31. Munoz, P. R., Correia, R. M., \& Nascimento, A. N. (2007). Energy and fuel, V.21, 295 - 302.

32. Cavalcante, C., \& Paulode, J. (2018). Elsevier, V. 220, $631-637$.

33. Yurchenko, O. I. (2015). Himikometrologicheskoe obuglevodorodovdobuce uglevodorodov. (p.222). X.: Folio. 